

Original Research Article

http://dx.doi.org/10.20546/ijcmas.2017.601.040

\title{
Influence of Sibinin on DMBA Induced Hepatotoxicity and Free-Radical Damage in Norwegian Rat, Rattus norvegicus $(L)$.
}

\author{
Vitthalrao B. Khyade* \\ Sericulture Unit, Malegaon Sheti Farm, Agricultural Development Trust Baramati, Shardanagar, \\ (Malegaon Khurd) Post Box No.- 35 Tal. Baramati, Dist. Pune 413115 Maharashtra, India \\ *Corresponding author
}

\section{A B S T R A C T}

7, 12-Dimethylbenz[a]anthracene (DMBA) is acting as immunosuppressor and it serves as a tumor initiator. Tumor promotion can be induced with treatments of 12-Otetradecanoylphorbol-13-acetate (TPA) in some models of two-stage carcinogenesis. This allows for a greatly accelerated rate of tumor growth, making many cancer studies possible. The DMBA damages many internal organs including liver, by inducing the production of reactive oxygen species, DNA-adduct formation and affecting the activities of phase I, II, antioxidant and serum enzymes. The silibinin is a pharmacologically active constitute of Silybummarianum (L), with documented antioxidant activity. The aim of present attempt was to evaluate both histopathologically and biochemically whether silibinin is protective in DMBA induced liver damage. Thirty two Norwegian Rats (Rattus

Keywords

DMBA; Oxidative

Stress;

Antioxidants;

Histopathology;

Liver.

\section{Article Info}

Accepted:

18 December 2016 Available Online: 10 January 2017 norvegicus L) were divided into four groups, as follows: 1) control group - oral corn oil was given; 2) DMBA group -DMBA was administered orally $335 \mathrm{mg} / \mathrm{kg}$ in the corn oil solution; 3) Silibinin group - $100 \mathrm{mg} / \mathrm{kg} /$ day silibinin was given alone orally, every 24 hours for 7 days; 4) Silibinin + DMBA group - DMBA plus silibinin was given. All rats were sacrificed at the end of experiment. Superoxide dismutases (SOD), glutathione peroxidase (GPX), nitric oxide (NO) and myeloperoxidase (MPO) were investigated in serum and liver tissue. In addition, serum aspartate aminotransferase (AST) and alanine aminotransferase (ALT) enzyme activities were evaluated. The liver tissue was evaluated histopathologically with Hematoxilin\& Eosin dye. Biochemically, ALT, AST, NO, MPO in serum and NO, MPO in liver tissue were found to be significantly higher in DIMBA group, compared to control group $(\mathrm{P}<0.001)$. In Group Silibinin + DMBA, serum AST, ALT, NO, MPO levels were significantly lower $(\mathrm{P}<0.01)$, and both serum and tissue SOD activities were significantly higher, compared to DMBA group ( $\mathrm{P}<0.001)$. DMBA induced histopathological changes in liver tissue were: severe sinusoidal dilatation, moderate disruption of the radial alignment of hepatocytes around the central vein, severe vacuolization in the hepatocyte cytoplasm, inflammation around central vein and portal region. In rats receiving both DMBA and silibinin, the DMBA induced changes accounted for less sinusoidal dilatation, vacuolization in the hepatocyte cytoplasm and the inflammation around central vein and portal region $(\mathrm{P}<0.05)$. The DMBA was found to induce liver damage by oxidative stress mechanisms. Silibinin reduced the oxidative stress by inducing antioxidant mechanisms, thereby showing protective effect against DMBA induced liver damage. Further studies with silibininshould be performed regarding DMBA toxicity. 


\section{Introduction}

7, 12-Dimethylbenz[a] anthracene (DMBA) is an immunosuppressor and a powerful organspecific laboratory carcinogen (Miyata et al., 2001). It is widely used in many research laboratories studying cancer. It serves as a tumor initiator. Tumor promotion can be induced with treatments of 12-O tetradecanoylphorbol-13-acetate (TPA) in some models of two-stage carcinogenesis (Sung et al., 2005). This allows for a greatly accelerated rate of tumor growth, making many cancer studies possible.

Silibinin is the major active constituent of silymarin, a standardized extract of the milk thistle seeds, containing a mixture of flavonolignans consisting of silbinin, isosilbinin, silicristin, silidianin, and others. Silibinin itself is mixture of two diastereomers, silybin A and silybin B, in approximately equimolarratio (Davis-Searles et al., 2005 ). The mixture exhibits a number of pharmacological effects, particularly in the liver, and there is some clinical evidence for the use of silibinin as a supportive element in alcoholic and child grade 'A' liver cirrhosis (Saller et al., 2008).

Poor water solubility and bioavailability of silymarin led to the development of enhanced formulations. Silipide (trade name Siliphos), a complex of silymarin and phosphatidylcholine (lecithin), is about 10 times more bioavailable than silymarin (Kidd and Head, 2005). An earlier study had concluded Siliphos to have 4.6 fold higher bioavailability(Barzaghi, 1990). It has been also reported that silymarin inclusion complex with $\beta$-cyclodextrin is much more soluble than silymarin itself (Voinovich, 2009). There have also been prepared glycosides of silybin, which show better water solubility and even stronger hepatoprotective effect (Kosina et al., 2002).
Silymarin, as other flavonoids, has been shown to inhibit P-glycoprotein-mediated cellular efflux (Zhou and Chowbay, 2004). The modulation of P-glycoprotein activity may result in altered absorption and bioavailability of drugs that are Pglycoprotein substrates. It has been reported that silymarin inhibits cytochrome P450 enzymes and an interaction with drugs primarily cleared by P450s cannot be excluded (Wu et al., 2009).

A phase I clinical trial in humans with prostate cancer designed to study the effects of high dose silibinin found 13 grams daily to be well tolerated in patients with advanced prostate cancer with asymptomatic liver toxicity (hyperbilirubinemia and elevation of alanine aminotransferase) being the most commonly seen adverse event (Thomas, 2007). Silymarin is also devoid of embryotoxic potential in animal models (Fraschini et al., 2002 and Hahn et al., 1968).Silibinin is under investigation to see whether it may have a role in cancer treatment (e.g. due to its inhibition of STAT3 signalling) (Bosch-Barrera and Menendez, 2015). Silibinin also has a number of potential mechanisms that could benefit the skin. These include chemoprotective effects from environmental toxins, anti-inflammatory effects, protection from UV induced photocarcinogenesis, protection from sunburn, protection from UVBinduced epidermal hyperplasia, and DNA repair for UV induced DNA damage (double strand breaks) (Singh et al., 2009).

Silibinin is a pharmacologically active constitute of Silybummarianum (Trappoliere et al., 2009). Its antioxidant activity may have a crucial role in the effects of silibinin. It is widely used in the treatment due to its safety and lack of adverse effects (Trouillas et al., 2008). Recent studies have shown that silibinin protects the liver against multiple 
drugs and chemical induced liver injury (Gazak et al., 2007; Prabu et al., 2012). Silibinin seems to be a promising protective agent for repairing free-radical induced damage in a variety of pathological conditions (Prabu et al., 2012). Aspartate aminotransferases (AST) and alanine aminotransferases (ALT) are intracellular aminotransferase enzymes, present in liver cells. After cell death or damage in liver cells, they are released into the circulation. Increased serum transaminases translate a susceptibility to liver damage (Andreoli et al., 1995). Myeloperoxidase (MPO) is the most abundant protein in neutrophils, catalyzes the conversion of hydrogen peroxide and chloride ions into hypochlorous acid. It plays a role in down regulating the inflammatory response (Klebanoff, 1999). Superoxide dismutase (SOD) is regarded as the first line of defense against the detrimental effects of molecular oxygen radicals in cells. Superoxide is a crucial source of hydroperoxides and free radicals. The activity of SOD inhibits lipid peroxidation by catalyzing the conversion of superoxides into hydrogen peroxide and oxygen. The SOD protects the cells from superoxide toxicity via removing superoxide free radicals (Beyer et al., 1991). Endogenous nitric oxide (NO) is formed from the amino acid L-arginine with nitric oxide synthase (NOS) enzyme. Increasing the level of NO has a crucial role in the modulation of oxidative stress and tissue damage (Tutanc et al., 2012). It was reported that oxidative stress results in the increase of the activity of $\mathrm{NO}$ synthase, as a consequence to the elevation of NO release (Peresleni et al., 1996). Glutathione peroxidase (GPx) is a crucial selenocysteine-containing enzyme, which catalyzes the reduction of hydroperoxides, including hydrogen peroxide, by reduced glutathione and functions to protect the cells from oxidative damage (Arthur, 2000). The attempt aimed to evaluate the antioxidant and protective efficacies of silibinin against DMBA induced hepatotoxicity in rats by evaluation of NO, MPO, SOD, GPx, AST, ALT and histological values.

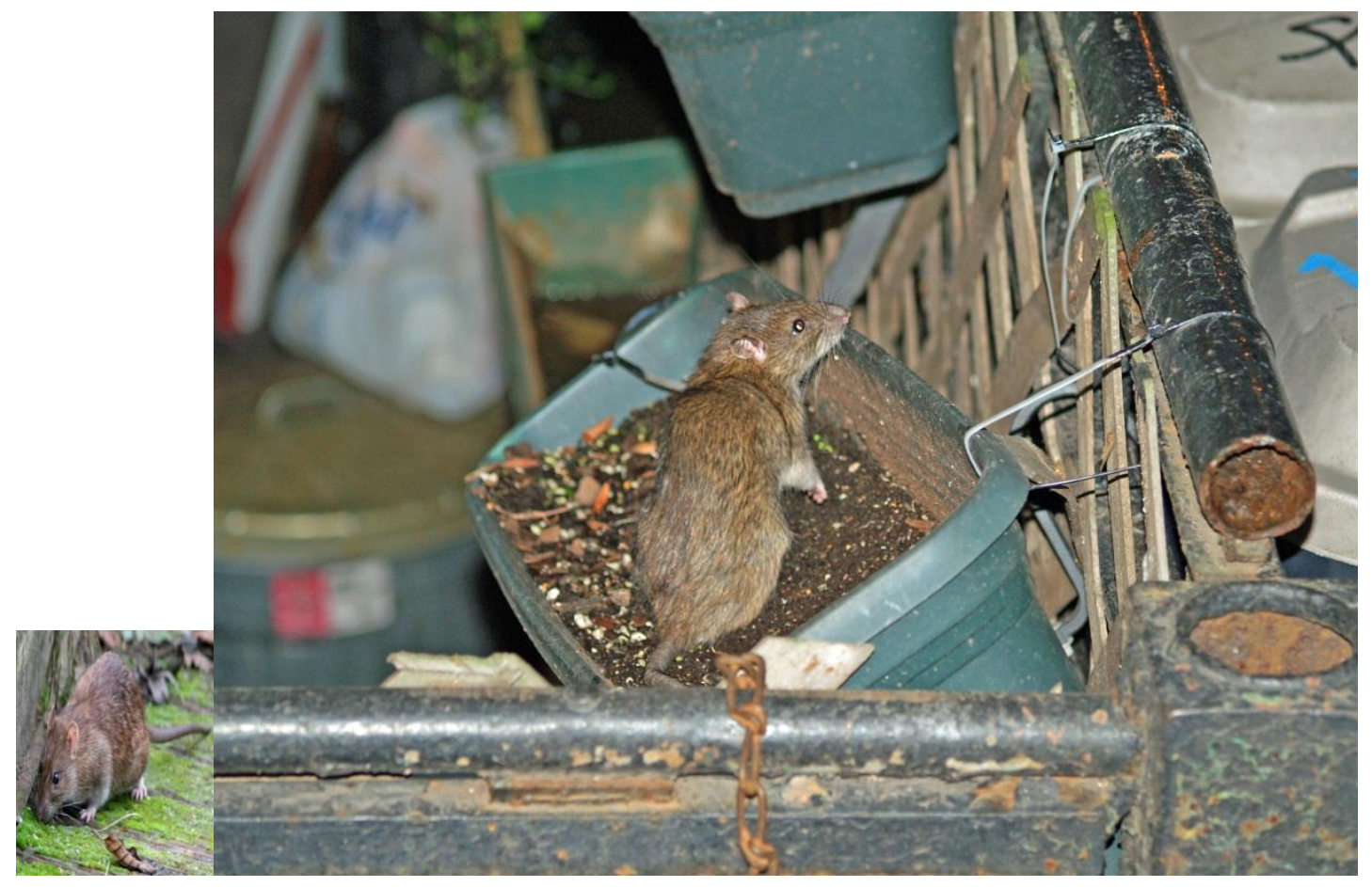




\section{Materials and Methods}

Thirty two adult female 12 week-old Brown rats (Rattus norvegicus L ) (Dr. APIS Laboratory), weighing 170 - $220 \mathrm{~g}$ were used for the present experiment. The animals were housed in quiet rooms $\left(20-25^{\circ} \mathrm{C} ; 50-60 \%\right.$ relative humidity) on a 12 hour light/dark cycle (7 a.m. - 7 p.m.) and allowed a commercial standard rat diet (Abalioglu Yem Sanayi, Denizli, Turkey) and water ad libitum. All animal procedures were approved by the Animal Care and Use Protocol (ACUP). DMBA and Silibinin were purchased from Sigma/Aldrich Chemicals, USA, through local dealer.

The animals were randomly divided into four groups: -

-Group 1: Control group $(\mathrm{n}=8)$; rats were given $0.3 \mathrm{~mL}$ corn oil orally;

- Group 2: DMBA group $(\mathrm{n}=8)$; rats were administered a single dose of $335 \mathrm{mg} / \mathrm{kg}$ of body weight (BW) of DMBA (Basudin 60 EC, Syngeta Tarım San. ve Tic. AS, Izmir, Turkey)with corn oil (Shah and Iqbal, 2010; Yilmaz et al., 2012 and Teimouri, 2007);

- Group 3: Silibinin group $(\mathrm{n}=8)$; silibinin was given orally, $100 \mathrm{mg} / \mathrm{kg} /$ day every 24 hours, for 7 days (Arthur, 2000 and Nakagawa and Moore, 1999);

- Group 4: DMBA + Silibinin group $(\mathrm{n}=8)$; rats were given DMBAsingle dose of 335 $\mathrm{mg} / \mathrm{kg}$ BW of DMBA orally and $100 \mathrm{mg} / \mathrm{kg} /$ day silibinin was administered orally, every 24 hours for 7 days.

At the end of the experiment, all animals were anesthetized under intraperiteoneal injection of ketamine/xylazine $(60 \mathrm{mg} / \mathrm{kg}$ and $6 \mathrm{mg} / \mathrm{kg}$, respectively). Blood samples were taken from intracardiac on the sterile tubes, for measuring the level of serum ALT, AST, MPO, NO, SOD and GPx. Blood samples were centrifuged and serum was separated. The blood was centrifuged at $2000 \times \mathrm{G}$ for 15 minutes, at $4^{\circ} \mathrm{C}$. The top yellow serum layer was pipetted off, without disturbing the white buffy layer. Livers were removed immediately and washed with phosphate buffer solution $(\mathrm{PBS})(\mathrm{pH}=7.4)$ and then frozen promptly in a deep freezer for biochemical analysis. All samples were protected under $-80^{\circ} \mathrm{C}$ until analysis.

\section{Determination of Aspartate Aminotransferase and Alanine Aminotransferase Activities: The activities of AST and ALT were calculated spectrophotometrically in serum, using Beckman Coulter kits by autoanalyzer (Unicel D × C 800 Synchron, Brea, California, USA).}

The results were expressed as units per liter (U/L).

Determination of Superoxide Dismutase Activity: The tissue was homogenized at $16000 \mathrm{rpm}$ on ice, in $5-10 \mathrm{~mL}$ cold buffer, $20 \mathrm{mM}$ HEPES buffer, pH 7.2, containing $1 \mathrm{mM}$ EGTA, $210 \mathrm{mMmannitol}$ and $70 \mathrm{mM}$ sucrose per $\mathrm{g}$ tissue. The mixture was centrifuged at $1500 \times \mathrm{G}$ for 5 minutes, at $4^{\circ} \mathrm{C}$. The supernatant was removed. Serum should be diluted 1:5 with sample buffer. The SOD activity was measured in the supernatant and serum. The SOD was determined via Cayman's Superoxide Dismutase assay kit (Cayman Chemical Co., Ann Arbor, MI, USA) in Bio-Tek ELx-800 (Winooski, USA). The detection of superoxide radicals were generated by xanthine oxidase and hypoxanthine. One unit of SOD is defined as the amount of enzyme required to exhibit $50 \%$ dismutation of the superoxide radical. The results were expressed as units per mg protein $(\mathrm{U} / \mathrm{mg})$ tissue, for liver tissue, and units per milliliter $(\mathrm{U} / \mathrm{mL})$ for serum. The 
dynamic range of the kits is $0.005-0.05$ $\mathrm{U} / \mathrm{mL}$ SOD. Recommended by the company for measuring formulation, the SOD was calculated by applying SOD values.

\section{Determination of Glutathione Peroxidase Activity:}

The tissue was homogenized in 5-10 mL cold buffer (50 mMTris-HCl, $\mathrm{pH} 7.5,5 \mathrm{mM}$ EDTA and $1 \mathrm{mM}$ DTT (Dithiothreitol) per tissue. Then, it was centrifuged at $10000 \times \mathrm{G}$ for 15 minutes, at $4^{\circ} \mathrm{C}$. The supernatant was removed after centrifugation. The blood was centrifuged at $700-1000 \times \mathrm{G}$ for 10 minutes, at $4^{\circ} \mathrm{C}$. The serum was removed. The GPx activity was measured in liver tissue and serum samples. The GPx activity was determined via Cayman's GPx assay kit (Cayman Chemical Co., Ann Arbor, MI, USA) in Bio-Tek ELx-800. The GPx activity was measured indirectly by a coupled reaction with glutathione reductase. The oxidized glutathione was produced upon reduction of hydroperoxide by GPx. The results were expressed as units per $\mathrm{mg}$ protein $(\mathrm{U} / \mathrm{mg}$ ) tissue, for liver tissue, and units per milliliter $(\mathrm{U} / \mathrm{mL})$, for serum. The dynamic range of the assay is only limited by the accuracy of the absorbance measurement.

Determination of Nitric Oxide Level: The tissue was homogenized in PBS ( $\mathrm{pH} 7.4)$ and centrifuged at $10000 \times \mathrm{G}$ for 20 minutes to create the supernatant. Total NO assay was performed by spectrophotometry at $540 \mathrm{~nm}$ using nitrate/nitrite colorimetric assay kit (Cayman, Ann Arbor, Michigan USA) in BioTek ELx-800. The assay was based on nitrate and nitrite determinations. The nitrate and nitrite are the stable end products of the reaction of NO with molecular oxygen. The total accumulation of nitrate and nitrite in serum and liver tissue was measured. The results were expressed as $\mu \mathrm{m} / \mathrm{g}$ protein.
Determination of MPO Activity: The quantitative detection of MPO was used by an enzyme-linked immunosorbent assay (ELISA) kit (MPO Instant Elisa, eBioscience, Vienna, Austria) in Bio-TekELx- 800. The results were expressed as $\mathrm{ng} / \mathrm{mL}$ protein.

Histopathology of Liver Tissue: The liver tissue was also removed for histopathological investigation. The specimens were fixed in $10 \%$ formalin subsequent overnight and then were dehydrated by immersion in a series of alcohol solutions of various concentrations, cleared in xylene and paraffin embedded tissue sections. The tissue samples were then infiltrated with paraffin as blocks, sectioned (5 $\mu$ m-thick slides). The prepared samples were examined under a light microscope according to the severity of the lesions modified from Yehiaet al (2007). Each parameter was scored between 0 and 3 (0: normal, 1: mild, 2: moderate and 3: severe) and according to the point total, lesions were classified into three grades (grade 1: 1-5 points, grade 2: 6 - 10 points and grade 3: 1115 points) (Andreoli et al., 1995 and Klebanoff, 1999).

Six parameters of liver damage were evaluated:

1. Sinusoidal dilatation;

2. Distortion radial alignment around central vein;

3. Vacuolization in hepatocytes;

4. Inflammation in the portal area and around central vein;

5. Hepatocellular necrosis;

6. Eosinophils infiltration of in the periportal field or around central vein.

Statistical Analysis: Data were analyzed using a commercially available statistics software package (SPSS Statistics for Windows, Version 20.0. IBM Corp., Armonk, NY, USA). All data were presented as the 
mean \pm SD for comparisons. Comparisons between groups were performed using the KruskalWallis analysis of variance for unpaired comparisons, followed by the Mann Whitney $\mathrm{U}$ test. The $\mathrm{P}<0.05$ was considered significant.

\section{Results and Discussion}

\section{Biochemical Results}

The levels of NO and MPO in serum and liver tissue were found to be significantly increased in the DI group, compared to control group (P $<0.0001$ ) (Tables 1 and 2). The activity of ALT and AST were found to be significantly increased in DI group, compared to control group $(\mathrm{P}<0.001)$ (Table 1). The levels of NO and MPO in serum were found to be significantly decreased in DMBA + silibinin group, compared with DI group $(\mathrm{P}<0.01$ and $\mathrm{P}<0.001)$. When comparing DMBA + silibinin group to DMBA group the activities of AST and ALT were found decreased (Tables 1 and 2). There was no significant statistical difference between the tissue or serum GPx activities, for all groups. The serum and tissue SOD activity was found increased in DMBA + silibinin group, when compared to DI group $(\mathrm{P}<0.001)$ (Table 1$)$.

\section{Histopathological Results}

Hepatocytes of control group (Figure 1 A) and silibinin group (Figure 1 B) were observed to have a normal structure (Figure 1). It was determined histopathologically that the liver tissue intoxicated by DMBA was significantly damaged (Grade 3).

In histopathological examination, rats administered DMBA showed severe sinusoidal dilatation, moderate disrupt radial alignment of hepatocytes, severe vacuolization of hepatocyte cytoplasm, and centrilobular necrosis $(\mathrm{P}<0.05)$ (Figure 2$)$. In contrast, rats in DMBA + Silibinin group exhibited these changes significantly, especially inflammation around the central vein and portal space $(\mathrm{P}<0.05)$ (Figure 3$)$.

The levels of ALT, AST, NO and MPO in serum were found increased in DI group, when compared with control group. We suggest that DMBA induced a significant liver damage. Silibinin reduced the levels of AST, ALT, NO, MPO in silibinin + DMBA group, compared with DI group. Silibinin, given to rats with DMBA, showed a significant protective activity against liver damage induced by DMBA. In addition, the level of SOD in serum and liver tissue increased via silibinin in silibinin+DMBA group (Table 2). In histopathological examination, DMBA caused severe sinusoidal dilatation and severe vacuolation, inflammation around the portal area and central vein and disrupted the radial alignment around the central vein in hepatocytes. Silibinin significantly reversed the DMBA-induced sinusoidal dilatation, severe vacuolization and inflammation around the central vein in hepatocytes $(\mathrm{P}<0.05)$ (Yehia et al., 2007 and Alp et al., 2011). The liver is a very crucial organ for the detoxification processes and oxidative stress is thought to be a key mechanism of hepatocellular injury. The liver tissue was the major site of DMBA metabolism, by assembling a great quantity of its metabolites (Giray et al., 2011). In the present study, we suggest that DMBA increased the reactive oxygen species (ROS) in liver tissue and silibinin carries out free-radical-eliminating activity and extensive antioxidant effect. Similarly, in previous studies, it was been shown that DMBA caused increases in lipid peroxidation (Yilmaz et al., 2012and Akturk et al., 2007). It was reported that DMBA exposure has been implicated in inducing oxidative stress increased nitrate and nitrite. The MPO, which is a peroxidase enzyme that 
synthetizes hypochlorous acid from $\mathrm{H} 2 \mathrm{O} 2$ and chloride, plays an important role, as a powerful oxidant, which utilizes free radicals (Klebanoff, 1999;Mehta et al., 2009; Klebanoff, 2005;Heinecke et al., 1993 ). In this study, DMBA exposure could induce oxidative stress by the increased NO, MPO concentrations, which should induce membrane lipid peroxidation, resulting in liver injury. These results were correlated with previous reports of Messarahet al. who showed DMBA might generate ROS (Messarah et al., 2013). It was reported that silibinin has antioxidant effects (Sozmen et al., 2014). To the best our knowledge, the current study is the first to investigate the silibinin antioxidant effects on DMBA induced hepatotoxicity. Oxidative stress induced by DMBA administration is also demonstrated by a highly significant increase in the activities NO and MPO and our results are in agreement with previous reports (Messarah et al., 2013Sozmen et al., 2014). The DMBA affects the mitochondrial membrane transportation in rat liver (Nakagawa and Moore 1999). Diazinon(Lee et al., 1991)and DMBA (Vitthalrao B. Khyade et al., 2014)binds extensively to biological membranes, especially to the phospholipids bilayers. Silibinin acts on the polar head group of phospholipids of the cellular membrane. It was reported that silibinin act as an excellent protective agent against lipid peroxidation on cellular membrane (Erlejman et al., 2004). Previous studies have reported the protective role of silibinin via scavenging free radicals and antioxidant properties (Gazak et al., 2007). Silibinin is membranotropic in nature and it has been found to bind firmly to the hepatocellular membrane. Silibinin has a role in metabolic and cell-regulating actions via antioxidative mechanism, which is regarded as a major hepatoprotective effect. In addition, ALT and AST enzymes activities represent a marker of hepatic function when determining hepatotoxicity. The DMBA exposure resulted in the increase of the activities of serum AST and ALT. The phenomenon may occur due to disturbing the transport function of the hepatocytes. In a previous study, silibinin repair function in hepatotoxicity was reported thorough the reduction in the serum levels of ALT and AST enzymes (Cacciapuoti et al., 2013). Probably, increases of serum ALT and AST enzymes activities are one of the important markers for the diagnosis of liver damage. In addition, by increasing MPO, NO levels, DMBA plays role in pathogenesis of hepatic toxicity via oxidative stress mechanism. The MPO, which is the most abundant protein in neutrophils and catalyzes the conversion of hydrogen peroxide and chloride ions into hypochlorous acid, plays a role in downregulating the inflammatory response (Klebanoff, 1999). However, in noninfectious diseases, MPO that was found increased was associated with strong oxidative activity. The activity of MPO in the oxidation of DMBA was reported previously (Lazarević-Pašti, 2011). Silibinin counteracted the inflammatory process by decreasing the MPO pathway and also by preventing free radical production. Liver injury, marked as centrilobular necrosis and neutrophilic infiltration around centrilobular area, could be seen in $\mathrm{H} \& \mathrm{E}$ stained rat liver cells. In this study, the activity of MPO and histopathological results are correlated about hepatotoxicity. Silibinin has been intensively studied in vitro, in vivo and also, in clinical trials. Van Wenumet al( 2013 ) reported that silibinin used in the treatment of cirrhosis, hepatitis and alcohol-induced liver disease, is usually connected with antioxidant action (van Wenum et al., 2013). Silibinin is extensively applied due to its safety and lack of adverse effects. We found an increased activity of plasma antioxidant enzymes, namely SOD in DMBA + silibinin group. The SOD is assumed to be the most effective 
antioxidant (Sirmali et al., 2013). Therefore, it is regarded as the first line of defense against the detrimental effects of molecular oxygen radicals in cells. Superoxide is a crucial source of hydroperoxides and free radicals. The activity of SOD inhibits lipid peroxidation by catalyzing the conversion of superoxides into hydrogen peroxide and oxygen (Beyer et al., 1991;Vitthalrao B. Khyade and Aziz Sancer, 2016). The SOD protects the cells from superoxide toxicity via removing superoxide free radicals. Silibinin also restored SOD activity. The increased hepatic SOD activity we observed in the group treated with silibinin. Accordingly, the coadministration of silibinin, after DMBA exposure, increased SOD levels and ameliorated the oxidative system. The coadministration of silibinin reduced the detrimental effects of DMBA by possibly scavenging or neutralizing ROS. These results showed that silibinin might have a beneficial role in lowering DMBA toxicity. Furthermore, a protective effect of silibinin has also been reported against $\mathrm{N}$ nitrosodimethylamine induced oxidative stress. Silibinin caused increases of SOD in liver tissue against $\mathrm{N}$-nitrosodimethylamine (Ezhilarasan et al., 2012; Vitthalrao B. Khyade, 2016).Lipid peroxidation starts as a consequence of ROS-induced isolation of hydrogen from polyunsaturated fatty acids (PUFAs) from the cellular membrane, which results in the formation of relatively stable compounds, like NO. Increasing the level of NO has a crucial role in the modulation of oxidative stress and tissue damage (Tutanc et $a l ., 2012)$. It was reported that oxidative stress results in increasing the activity of $\mathrm{NO}$ synthase, as a consequence of the elevation of NO release (Peresleni et al., 1996). The DMBA induced the secretion of excess NO reaction with the superoxide anion to generate the peroxynitrite radical involved in the toxification process. Silibinin treatment significantly reduced lipid peroxidation, as an antioxidant. Therefore, silibinin treatment repaired the excess NO reaction.

\begin{tabular}{|l|l|c|c|c|c|c|}
\hline \multicolumn{7}{|c|}{ Table.1 Influence of Sibinin on Biochemical Parameteres of Serum in DMBA Induced } \\
Hepatotoxicity and Free-Radical Damage in Norwegian Rat, Rattus norvegicus (L).
\end{tabular}




\begin{tabular}{|c|c|c|c|c|}
\hline \multicolumn{5}{|c|}{$\begin{array}{l}\text { Table.2 Influence of Sibinin on Biochemical Parameteres of Liver in DMBA Induced } \\
\text { Hepatotoxicity and Free-Radical Damage in Norwegian Rat, Rattus norvegicus (L). }\end{array}$} \\
\hline Groups & GPx, U/mg & $\mathrm{SOD}, \mathrm{U} / \mathrm{mg}$ & $\mathrm{NO}, \mu \mathrm{m} / \mathrm{g}$ & $\mathrm{MPO}, \mathrm{ng} / \mathrm{mL}$ \\
\hline Control group & $0.89 \pm 0.21$ & $1.6 \pm 0.47$ & $2.86 \pm 1.84$ & $3.51 \pm 2.40$ \\
\hline DMBA group & $0.76 \pm 0.23$ & $2.70 \pm 1.71$ & $9.45 \pm 2.71$ & $7.54 \pm 3.32$ \\
\hline Silibinin group & $0.96 \pm 0.29$ & $3.84 \pm 1.48$ & $2.2 \pm 0.01$ & $4.56 \pm 2.26$ \\
\hline $\begin{array}{l}\text { DMBA + } \\
\text { Silibinin group }\end{array}$ & $0.18 \pm 0.11$ & $2.82 \pm 0.83$ & $5.9 \pm 1.14 \mathrm{c}$ & $3.73 \pm 1.11 \mathrm{~d}$ \\
\hline \multicolumn{5}{|c|}{$\begin{array}{l}\text {-Abbreviations: } \\
\text { GPX: Glutathione peroxidase; MPO: Myeloperoxidase; NO: Nitric oxide; } \\
\text { SOD: Superoxide dismutases. } \\
\text {-Data is presented as Mean } \pm \text { SD for } n=8 \text {. } \\
\text {-P }<0.05 \text { NO, DI + Silibinin, compared with DMBA group. } \\
-\mathrm{P}<0.05 \mathrm{MPO}, \mathrm{DI}+\text { Silibinin, compared with DMBA group. }\end{array}$} \\
\hline
\end{tabular}

Fig.1 Histological Structure of Liver in theNorwegian Rat, Rattus norvegicus (L).A: Untreated Control Group(H \& E × 40) B:SilibininTreated Group Group (H \& E × 40).
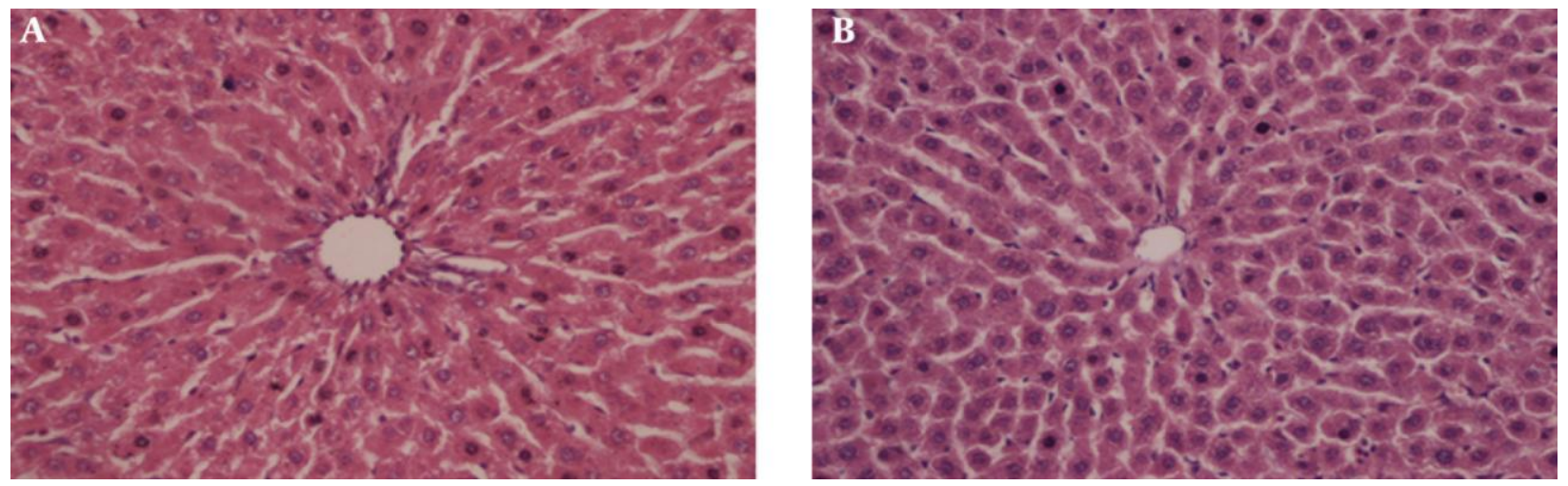

Fig.2 Histological Structure of Liver in theNorwegian Rat, Rattus norvegicus (L).DMBATreated Group. A: Dilatation in sinusoids (arrows) $(\mathrm{H} \& \mathrm{E} \times 40)$. B: Cellular disruption (stars) around central vein (arrow) (H \& E × 40). C:Vacuolation (arrows) (H \& E × 200). D: Mononuclear inflammatory cells (stars) among hepatic cells, around the central vein (arrow) and portal space (arrow head) (H \& E × 40). E: Hepatocel ᄀlular necrosis (stars) $(\mathrm{H} \& \mathrm{E} \times 40)$.
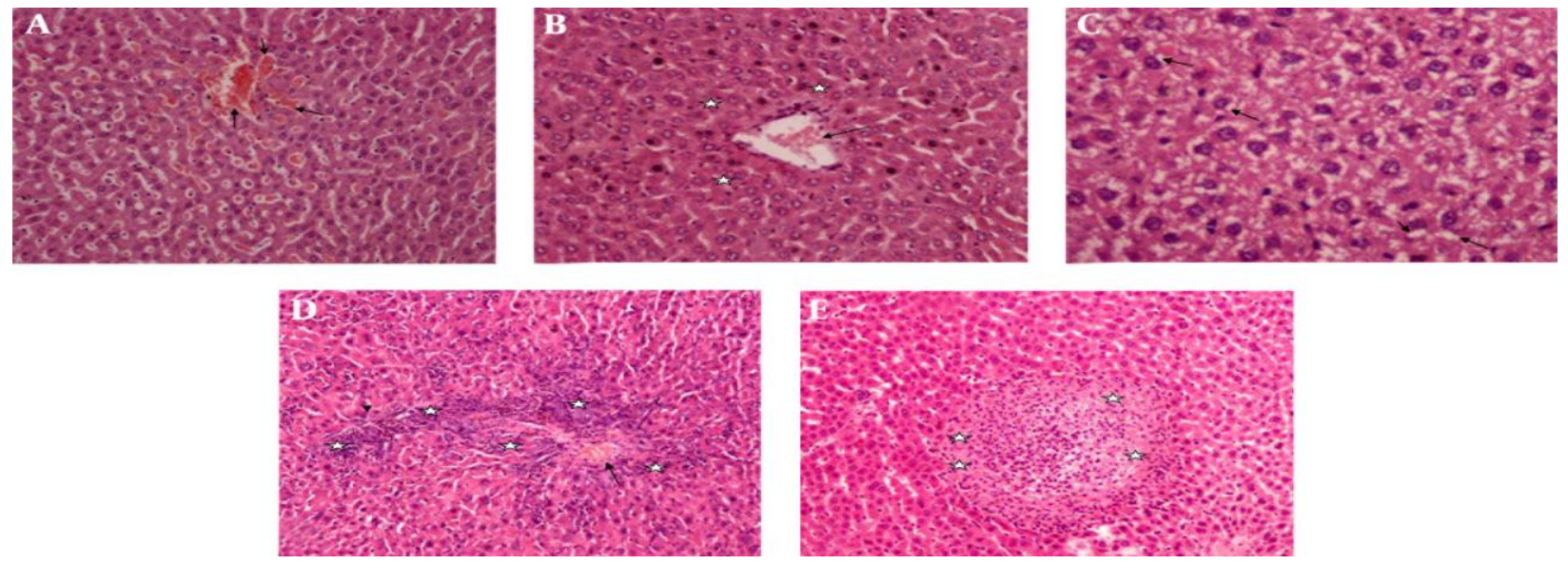
Fig.3 Histological Structure of Liver in the Norwegian Rat, Rattus norvegicus (L)(DMBA + Silibinin Group)A: Mild dilatation in sinusoid (arrows) $(\mathrm{H} \& \mathrm{E} \times 100)$. B: Minimal vacuolation (arrows) (H \& E × 200).

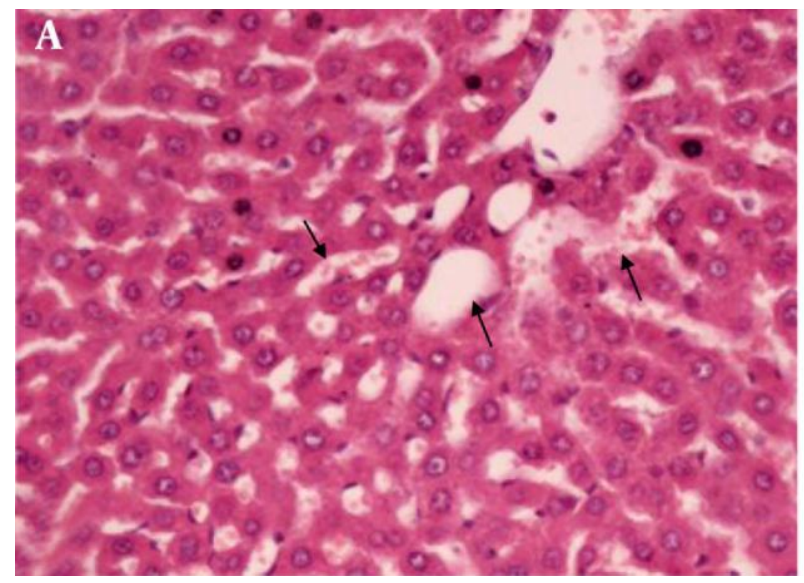

Treatment with silibinin effectively decreased the levels of NO. It has been reported that silibinin scavenges nitrogen species. Similarly, Prabuet al (2012) found that the level of NO decreased as a result of silibinin treatment against arsenic induced toxicity (Prabu et al., 2012; Vitthalrao B. Khyade and Sadhana D. Deshpande, 2015). The GPx is a crucial selenocysteine-containing enzyme, which catalyzes the reduction of hydroperoxides, including hydrogen peroxide, by reduced glutathione and functions to protect the cell from oxidative damage (Arthur, 2000; VitthalraoB. Khyade and Ujwala D. Lonkar, 2013). It was reported that DI induced oxidative toxicity through oxidation of GPx (Shadniaet al., 2011). In another study, the GPx activity values were found to be non-significantly different between the DMBA group and DMBA $+\mathrm{N}$ acetyl cysteine group. Similarly, in our study, GPx activity was not found significantly different between DMBA group and DIMBA + silibinin group.

Conclusively enough, the attempt demonstrate that silibinin exerts hepatoprotective, antioxidant, free radical scavenging effects against DMBA induced hepatotoxicity. It may be suggested that silibinin is convenient as a

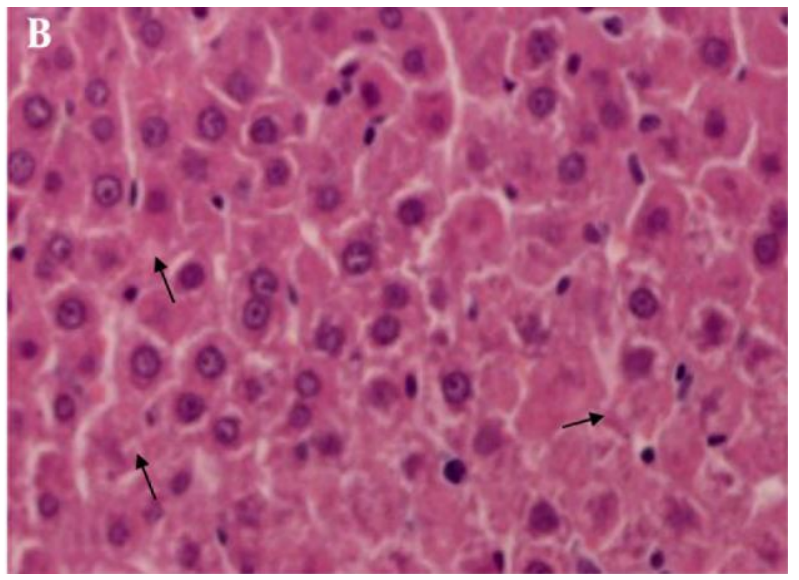

therapeutic agent for the amelioration of DMBA induced hepatotoxicity. However, further studies are required in order to understand and quantify the beneficial effects of silibinin in DMBA induced hepatotoxicity and it's possible clinical use.

Acknowledgements: The research paper is to wish "Happy Birthday" to Hon. Avram Hershko (31 December). The author would like to thank the head and staff members of the department of Zoology, SavitribaiPhule University, Pune for support and guidance. Experimental Research Center, Isparta, Turkey and MuglaSitki Kocman University Scientific Research Projects deserve appreciations and exert a grand salutary influence for financial and technical supports.

\section{References}

Akturk, O., Demirin, H., Sutcu, R., Yilmaz, N., Koylu, H., Altuntas, I. 2006. The effects of diazinon on lipid peroxidation and antioxidant enzymes in rat heart and ameliorating role of vitamin $\mathrm{E}$ and vitamin C. Cell Biol. Toxicol., 22(6):45561.

Alp, H., Aytekin, I., Esen, H., Basarali, K., Kul, S.2011. Effects of caffeic acid 
phenethyl ester, ellagic acid, sulforaphane and curcumin on diazinon induced damage to the lungs, liver and kidneys in an acute toxicity rat model. Kafkas Univ Vet Fak Derg., 17(6):92733.

Andreoli, T.E., Carpenter, C.C.J., Cecil, R.L.F. 1995. Cecil Essentials of Medicine. 3rd edMichigan: Saunders.

Arthur, J.R. 2000. The glutathione peroxidases. Cell Mol. Life Sci., 57(1314):1825-35.

Babita, M., Sakdeo and Vitthalrao, B. Khyade. 2013. Effect of moracin on dmba - tpa induced skin tumor formation in the mice. 2013. Int. J. Adv. Biol. Res., vol. 3 (4): 576 - 583. www.scienceandnature.org/IJABR.../In dex\%20IJABR-vol3(4).pdf

Barzaghi, N., Crema, F., Gatti, G., Pifferi, G., Perucca, E. 1990. "Pharmacokinetic studies on IdB 1016, a silybinphosphatidylcholine complex, in healthy human subjects". Eur. J. Drug Metab. Pharmacokinet., 15: $333-$ 8. PMID 2088770.

Beyer, W., Imlay, J., Fridovich, I. 1991. Superoxide dismutases. Prog Nucleic Acid Res. Mol. Biol., 40: 221-53.

Bosch-Barrera, J., Menendez, J.A. 2015. "Silibinin and STAT3: A natural way of targeting transcription factors for cancer therapy". Cancer Treat. Rev., (Review). 41 (6): 540-6. doi:10.1016/j.ctrv.2015.04.008. PMID 2 5944486.

Cacciapuoti, F., Scognamiglio, A., Palumbo, R., Forte, R., Cacciapuoti, F. 2013. Silymarin in non alcoholic fatty liver disease. World J. Hepatol., 5(3): 10913.

Davis-Searles, P., Nakanishi, Y., Nam-Cheol, K. et al. 2005. "Milk Thistle and Prostate Cancer: Differential Effects of Pure Flavonolignans from Silybummarianum on Antiproliferative
End Points in Human Prostate Carcinoma Cells". Cancer Res., 65(10): 4448-57. doi:10.1158/0008-5472.CAN04-4662.

Erlejman, A.G., Verstraeten, S.V., Fraga, C.G., Oteiza, P.I. 2004. The interaction of flavonoids with membranes: potential determinant of flavonoid antioxidant effects. Free Radic. Res., 38(12):131120.

Ezhilarasan, D., Karthikeyan, S., Vivekanandan, P. 2012. Ameliorative effect of silibinin against $\mathrm{N}$ nitrosodimethylamine-induced hepatic fibrosis in rats. Environ. Toxicol. Pharmacol., 34(3): 1004-13.

Fraschini, F., Demartini, G., Esposti, D. 2002. "Pharmacology of Silymarin". Clin. Drug Investigation, 22 (1): 5165. doi:10.2165/00044011-20022201000007.

Galloway, T., Handy, R. 2003. Immunotoxicity of organophosphorous pesticides. Ecotoxicol., 12(1-4):345-63.

Gazak, R., Walterova, D., Kren, V. 2007. Silybin and silymarin--new and emerging applications in medicine. Curr. Med. Chem., 14(3): 315-38.

Giordano, G., Afsharinejad, Z., Guizzetti, M., Vitalone, A., Kavanagh, T.J., Costa, L.G. Organophosphorus insecticides chlorpyrifos and diazinon and oxidative stress in neuronal cells in a genetic model of glutathione deficiency. Toxicol. Appl. Pharmacol., 219(23):181-9.

Giray, B., Gurbay, A., Hincal F. Cypermethrin-induced oxidative stress in rat brain and liver is prevented by vitamin E or allopurinol. Toxicol. Lett., 2001;118(3):139-46.

Hahn, G., Lehmann, H.D., Kürten, M, Uebel $\mathrm{H}$, Vogel G 1968. "On the pharmacology and toxicology of silymarin, an antihepatotoxic active 
principle from Silybum marianum (L.) gaertn". Arzneimittelforschung, 18 (6): 698-704. PMID 5755807.

Heinecke, J.W., Li, W., Francis, G.A., Goldstein, JA. Tyrosyl radical generated by myeloperoxidase catalyzes the oxidative cross-linking of proteins. $J$ Clin Invest., 91(6):2866-72.

Kidd, P., Head, K. 2005. "A review of the bioavailability and clinical efficacy of milk thistle phytosome: a silybinphosphatidylcholine complex (Siliphos)" (PDF). Alternative Med. Rev., 10 (3): 193-203.

Klebanoff, S.J. Myeloperoxidase. ProcAssoc Am Physicians., 111(5):383-9.

Klebanoff, S.J. Myeloperoxidase: friend and foe. J. Leukoc Biol., 2005; 77(5):598625.

Kosina, P., Kren, V., Gebhardt, R., Grambal F, Ulrichová J, Walterová. D. 2002. "Antioxidant properties of silybin glycosides". Phytotherapy Res., PTR. 16 Suppl 1: S339. doi:10.1002/ptr.796.

Lazarević-Pašti, T., Čolović, M., Savić, J., Momić, T, Vasić V. Oxidation of diazinon and malathion by myeloperoxidase. Pesticide Biochem Physiol., 00(2):140-4.

Lee, A.G., Malcolm, East, J., Balgavy P. Interactions of insecticides with biological membranes. Pesticide Sci., 32(3):317-27.

Mehta, A., Verma, R.S., Srivastava, N. 2009. Chlorpyrifos induced alterations in the levels of hydrogen peroxide, nitrate and nitrite in rat brain and liver. Pesticide Biochem. Physiol., 94(2-3): 55-9.

Messarah, M., Amamra, W., Boumendjel, A., Barkat, L., Bouasla, I., Abdennour C et al. Ameliorating effects of curcumin and vitamin $\mathrm{E}$ on diazinon-induced oxidative damage in rat liver and erythrocytes. ToxicolInd Health. 29(1):77-88.
Miyata, M., Furukawa, M., Takahashi, K., Gonzalez, F.J., Yamazoe, Y. 2001. "Mechanism of 7, 12Dimethylbenz[a]anthracene-Induced Immunotoxicity: Role of Metabolic Activation at the Target Organ". Jpn. J. Pharmacol., 86: 302309. doi:10.1254/jjp.86.302.

Nakagawa, Y., Moore, G. 1999. Role of mitochondrial membrane permeability transition in p-hydroxybenzoate esterinduced cytotoxicity in rat hepatocytes. Biochem. Pharmacol., 58(5): 811-6.

Peresleni T, Noiri E, Bahou WF, Goligorsky MS. Antisense oligodeoxynucleotides to inducible NO synthase rescue epithelial cells from oxidative stress injury. Am $J$ Physiol. 1996;270(6 Pt 2):F971-7.

Prabu, S.M., Muthumani, M. Silibinin ameliorates arsenic induced nephrotoxicity by abrogation of oxidative stress, inflammation and apoptosis in rats. MolBiol Rep. 2012;39(12):11201-16.

Rohit Arora; Sakshi Bhushan; Rakesh Kumar; Rahul Mannan; Pardeep Kaur; Amrit Pal Singh; Bikram Singh; Adarsh P. Vig; Deepika Sharma; and Saroj Arora (2014). Hepatic Dysfunction Induced by 7, 12Dimethylbenz $(\alpha)$ anthracene and Its Obviation with Erucin Using Enzymatic and Histological Changes as Indicators. PLoS One, 9(11): e112614.Published online $2014 \quad$ Nov 12. doi: 10.1371/journal.pone.0112614 https://www.ncbi.nlm.nih.gov/pmc/artic les/PMC4229223/

Saller, R., Brignoli, R., Melzer, J., Meier, R. 2008. "An updated systematic review with meta-analysis for the clinical evidence of silymarin". Forschende Komplementärmedizin. 15 (1): $\quad 9-$ 20. doi:10.1159/000113648. PMID 183 34810. Retrieved 2010-12-14. 
Shadnia, S., Ashrafivand, S., Mostafalou, S., Abdollahi, M. 2011. N-acetylcysteine a Novel Treatment for Acute Human Organophosphate Poisoning. Int. J. Pharmacol., 7(6).

Shadnia, S., Dasgar, M., Taghikhani, S., Mohammadirad, A., Khorasani, R, Abdollahi, M. 2007. Protective Effects of alpha-Tocopherol and N-AcetylCysteine on Diazinon-Induced Oxidative Stress and Acetylcholinesterase Inhibition in Rats. Toxicol. Mech. Methods. 17(2):109-15.

Shah, M.D., Iqbal, M. 2010. Diazinoninduced oxidative stress and renal dysfunction in rats. Food Chem. Toxicol., 48(12):3345-53.

Singh, Rana, P., Agarwal, Rajesh. September 2009. "Cosmeceuticals and silibinin". Clinics in Dermatol., 27 (5): 479484. doi:10.1016/j.clindermatol.2009.05 .012. PMC 2767273. PMID 19695480.

Sirmali, M., Solak, O., Tezel, C., Sirmali, R., Ginis, Z., Atik, D. et al. 2013. Comparative analysis of the protective effects of caffeic acid phenethyl ester (CAPE) on pulmonary contusion lung oxidative stress and serum copper and zinc levels in experimental rat model. Biol Trace Elem Res., 151(1): 50-8.

Sozmen, M., Devrim, A.K., Tunca, R., Bayezit, M, Dag S, Essiz D. Protective effects of silymarin on fumonisin $\mathrm{B}(1)$ induced hepatotoxicity in mice. $J$ Vet Sci., 15(1):51-60.

Sung, Y.M., He, G., Fischer, S.M. 2005. "Lack of Expression of the EP2 but not EP3 Receptor for Prostaglandin E2 Results in Suppression of Skin Tumor Development". Cancer Res., 65: 9304 9311. doi:10.1158/0008-5472.can-051015.

Teimouri, F., Amirkabirian, N, Esmaily H, Mohammadirad, A., Aliahmadi A, Abdollahi, M. 2006. Alteration of hepatic cells glucose metabolism as a non-cholinergic detoxication mechanism in counteracting diazinoninduced oxidative stress. Hum Exp. Toxicol., 25(12):697-703.

Thomas, W., Flaig, Daniel, L., Gustafson, Lih-Jen Su, Joseph A. Zirrolli; Frances Crighton; Gail, S. Harrison; A. Scott Pierson; Rajesh Agarwal; L. Michael Glodé. 2007. "A phase I and pharmacokinetic study of silybinphytosome in prostate cancer patients". Investigational New Drugs, 25(2): 139-146. doi:10.1007/s10637-006-9019-2.

Trappoliere, M., Caligiuri, A., Schmid, M., Bertolani, C., Failli P, Vizzutti F et al. Silybin, a component of sylimarin, exerts anti-inflammatory and antifibrogenic effects on human hepatic stellate cells. J. Hepatol., 50(6):110211.

Trouillas, P., Marsal, P, Svobodova A, Vostalova, J., Gazak ,R,. Hrbac J. et al. Mechanism of the antioxidant action of silybin and 2, 3-dehydrosilybin flavonolignans: a joint experimental and theoretical study. $J$ PhysChem., $A$. 112(5):1054-63.

Tůmová, L., Tůma, J, Megušar K, Doleža M 2010.

"Substituted

Pyrazinecarboxamides as Abiotic Elicitors of Flavolignan Production in Silybummarianum (L.) Gaertn Cultures in Vitro". Mol., 15 (1): 331340. doi:10.3390/molecules15010331.

Tutanc, M., Arica, V, Yilmaz N, Nacar A, Zararsiz I, Basarslan F et al. Effects of erdosteine on cyclosporin-A-induced nephrotoxicity. Hum Exp Toxicol., 2012; 31(6):565-73.

van Wenum, E., Jurczakowski, R., Litwinienko, G. 2013. Media effects on the mechanism of antioxidant action of silybin and 2, 3-dehydrosilybin: role of the enol group. J. Org. Chem., 78(18):9102-12. 
Vitthalrao, B. 2014. Khyade andRhidimJiwan P. Sarwade 2014. Influence of Moracin on DMBA - TPA induced cancer in the skin of mice, Musmusculus (L). Recent Trends in Zoology (Pages: 113-133). Editor: Dr. R.K. Kasa, Publisher: Dr. L. S. Matkar (Principal, New Arts, Commerce and Science College, Shevgaon Dist. Ahmednagar - 414502 (M.S.) India. ISBN: 978-93-84916-68-8.

Vitthalrao, B., Khyade and sharad G. Jagtap. 2016. Antioxidant activity and phenolic compounds of mulberry, Morus alba (L) (Variety: Baramatiwali) International Conference on "Plant Research and Resource Management" And 25 ${ }^{\text {th }}$ APSI Silver Jubilee Meet 2016 at T. C. College Baramati 11, 12 and 13 February, 2016. Pages: 374 - 377.

Vitthalrao, B., Khyade. 2016. Impact of Moracin on Hydrogen Peroxide induced oxidative stress in feline fibroblasts. Int. Academic J. Innovative Res., Vol. 3No.10: 45 - 59 . ISSN 2454390X. www.iaiest.com

Vitthalrao, B., Khyade. 2016. Induction of buccal pouch carcinoma through $7,12-$ dimethylbenz(a) anthracene (DMBA) in Syrian hamster, Mesocricetusauratus (L) and treatment with the ethanolic extractives of leaves of mulberry, Morus alba (L). Int. Academic J. Innovative Res., Vol. 3 No. 10: 68 - 83. ISSN 2454-390X. www.iaiest.com

Vitthalrao, B., Khyade, Suryakant, M. Mundhe and Shakir Ali Syed. 2015. Influence of Ethanolic Extractives of Leaves of Mulberry, Morus alba (L) On 7, 12-Dimethylbenz (A) Anthracene (DMBA) Induced Buccal Pouch Carcinoma in Syrian Hamster, Mesocricetusauratus (L). IOSR J. Pharmacy and Biol. Sci., (IOSR-JPBS) e-ISSN: 2278-3008, p-ISSN:2319-7676.
Volume 10, Issue 1 Ver. IV (Jan -Feb. 2015), PP 69-75www.iosrjournals.org Vitthalrao, B., Khyade, Vivekanand, V. Khyade, Sunanda V. Khyade and MayBritt Moser. 2014. Influence ofMoracin on DMBA-TPA induced skin tumerigenesis in the mouse. Int. J. Bioassays, 3(11): 3510 - 3516. ISSN: 2278-778X. www.ijbio.com

Vitthalrao, B., Khyade and Sadhana, D. Deshpande. 2015. Chemopreventive Efficacy Of Ethanolic Extractives Of Leaves Ofmulberry, Morus Alba (L) On 7, 12-Dimethylbenz(A) Anthracene (Dmba)Induced Buccal Pouch Carcinoma In Syrian Hamster, Mesocricetus Auratus (L). Int. J. Recent Scientific Res., Vol. 6, Issue, 3, pp.3156-3161, March, 2015. www.recentscientific.com

Vitthalrao, B., Khyade and Ujwala, D. Lonkar. 2013. Effect of Moracin on DMBA - TPA induced cancer in mice, Musmusculus(L). Annals of Plant Sci., Vol. 2 No. 10 (2013):412 - 419. http://ebioscholar.com/ojs/index.php/ap/ article/view/628/528

Vitthalrao, B., Khyade, Vivekanand, V. Khyade and Sunanda, V. Khyade. 2013. Use of Moracin in preventing the cancer. J. Environ. Sci. Toxicol. Food Technol., (IOSR-JESTFT) e-ISSN:23192402, p- ISSN: 2319-2399. Volume 4, Issue 5 (May. - Jun. 2013), PP 96104www.Iosrjournals.Org

Vitthalrao, B., Khyade1 and Aziz Sancer. 2016.Treating the 7, 12dimethylbenz(a)anthracene (DMBA) induced buccal pouch carcinoma in Syrian hamster, Mesocricetusauratus $(\mathrm{L})$ with ethanolic extractives of leaves of mulberry, Morus alba (L).World Scientific news 30 (2016): 1-13. www.worldscientificnews.com

Voinovich, D., Perissutti, B., Grassi, M., Passerini, N., Bigotto, A. 2009. "Solid 
state mechanochemical activation of Silybummarianum dry extract with betacyclodextrins: Characterization and bioavailability of the coground systems".J. Pharmaceutical Sci., 98(11): 4119 29. doi:10.1002/jps.21704. PMID 19226 635.

Wu, J.W., Lin, L.C., Tsai, T.H. 2009. "Drugdrug interactions of silymarin on the perspective of pharmacokinetics". $J$. Ethnopharmacol., 121(2): 185 93. doi:10.1016/j.jep.2008.10.036. PMI D 19041708. Retrieved 2010-12-14.

Yehia, M.A., El-Banna, S.G., Okab, A.B. 2007. Diazinon toxicity affects histophysiological and biochemical parameters in rabbits. Exp. Toxicol. Pathol., 59(3-4): 215-25.

Yilmaz, N., Yilmaz, M., Altuntas, I. 2012.Diazinon-induced brain toxicity and protection by vitamins $\mathrm{E}$ plus $\mathrm{C}$. Toxicol. Ind. Health, 28(1): 51-7.

Zarichi Baghlani, K., Saberi, M., Rasooli Vani, J. 2011. Protective effects of guanosine on Diazinon induced oxidative stress in neuralgia U373MG cell line. Trauma Mon, 16(3): 157-61.

Zhou, S., Lim, L.Y., Chowbay, B. 2004. "Herbal modulation of P-glyco protein". Drug Metabolism Reviews, 36(1): $57 \quad-104, \quad$ doi: 10.1081/DMR120028427. PMID 15072439.

\section{How to cite this article:}

Vitthalrao B. Khyade. 2017. Influence of Sibinin on DMBA Induced Hepatotoxicity and FreeRadical Damage in Norwegian Rat, Rattus norvegicus (L).Int.J.Curr.Microbiol.App.Sci. 6(1): 324-338. doi: http://dx.doi.org/10.20546/ijcmas.2017.601.040 